\title{
Concepción Cabrillana Leal, Consideración sintáctico-semántica de esse. Un estudio a través de la prosa de Livio, Santiago de Compostela, Universidade, Lalia series maior 23, 2010, $138 \mathrm{pp}$.
}

Decir sintaxis latina es evocar la referencia de una larga historia de estudios gramaticales. El enfoque de estos estudios ha ido descubriendo misterios del lenguaje y de la comunicación que han podido ser descritos de manera objetiva, aunque incompleta. Esta característica no deriva solamente del observador, pues es difícil hacer conscientes tantos mecanismos sin dejar algún cabo suelto para que otros lo anuden. Se trata de un ejercicio de abstracción de las tendencias que condicionan la disposición de la secuencia verbal en el discurso. Esta disposición se va definiendo en estructuras repetidas que de manera consciente o inconsciente permiten la generación inteligible de mensajes. Pero el reconocimiento de una repetición sistemática no supone en absoluto una regularidad perfecta, entre otros motivos, por la interdependencia entre los niveles en que se articula el lenguaje. Por eso la información que no está claramente definida en el nivel fonemático o en el morfológico, o en el sintáctico, se completa con la que aportan las diferencias semánticas que se insertan en esos niveles distintos. También la disposición sintáctica depende en cierta medida de esas noticias semánticas, o más bien cuenta con ellas. De ahí la "consideración sintáctico-semántica". Y de ahí también que la autora, teniendo en cuenta los estudios precedentes, se anime a hacer una "consideración" corroborada por un análisis de la frecuencia con que se repiten las estructuras en un texto amplio y de variada temática como es la historia de Livio.

El estudio ponderado de ciertas disposiciones y caracteres semánticos se presenta en una gradación de límites desde menor a mayor relevancia semántica del verbo y de las demás clases de palabras que constituyen el discurso. La orientación metodológica de esta monografía se anuncia desde las primeras páginas. El tema tenía raíces muy antiguas en la especulación filosófica sobre el lenguaje, y aún mantiene su interés para la lingüística general, porque analiza uno de los rasgos estructurales más característicos de las lenguas europeas. El método con que se efectúa este análisis desarrolla la línea de investigación seguida por la Gramática Funcional en la Escuela de Ámsterdam específicamente para el latín. Este modo de acceso al comportamiento sintáctico del verbo esse se funda en el razonamiento sobre la formalización de las posiciones y relaciones verbales en la configuración de la frase al servicio de nociones significativas en marcos predicativos. Estos marcos contribuyen decisivamentea facilitar la clasificación de los usos de acuerdo con las nociones semánticas fundamentales. Este instrumento de descripción añade un valor importante a este trabajo. Se recoge de modo ordenado en cada capítulo cuando se revisa consecuentemente el esquema que se puede asignar a cada estructura, habida cuenta de los ejemplos comentados y de las opiniones recogidas. Los esquemas estructurales más representativos mantienen una referencia abreviada a través de la discusión de los aspectos más relevantes. 
Destaquemos la novedosa interpretación mediante el análisis de la formalización semántica de la construcción atributiva latina, de la sintaxis del dativo, del genitivo y la designación existencial-locativa.

Un complemento interesante de esta descripción del funcionamiento sintáctico de esse es la figura contrapuesta de los verbos asociados por la evolución de la lengua latina, vigentes aún en nuestras lenguas romances. En efecto, a pesar de que la teoría sintáctica pretende la formalización de las descripciones lingüísticas, estas formas no existen despojadas de su materia, fuera de una lengua concreta. Por eso, toda descripción, si se desea precisa, y por muy formal que se quiera, adquiere mayor propiedad si cuenta con una correspondencia con otra lengua o lenguas. Ahora bien, el latín ha sido estudiado por hablantes de lenguas romances y por los que tienen una lengua materna diferente al ámbito románico, y esta múltiple perspectiva, con ocasionales coincidencias, ofrece todavía un aspecto más ajustado. Así lo procuraba la autora en su discusión de las definiciones y acuerdos entre los gramáticos que escriben en diferentes lenguas.

La conexión significativa entre el nivel sintáctico y el semántico resulta notable en las estructuras características de este verbo con mayor motivo, pues la realización de una variedad de construcciones permite una variedad de usos en la expresión. En este aspecto, la crítica a la hipótesis de la cúpula-soporte evita incurrir en el exceso de atribuir la mayoría de las nociones a las estructuras focalizadas con el auxilio de este verbo. Por eso, la exposición se decanta por presentar gradualmente la extensión y complejidad que adoptaban en latín las estructuras con esse, al tiempo que se desgrana la capacidad de expresión semántica. Desde las construcciones monovalentes de existencia, se pasa por 'actuar como/llegar a ser' (en comparación con otros verbos como exsto, existo, euenio, uiuo). Para ilustración de esta especie de paradigma gradual se recurre al apoyo en la evolución seguida por otras lenguas y a la perspectiva pragmática, que muestra la contigüidad de estas dos construcciones en el uso de la lengua latina. Esta comparación se establece mediante los rasgos semánticos que caracterizan a los argumentos relacionados por la construcción (animado, definido, concreto, control, dinámico), en una gradual escala entre verbos predicacionalmente completos, semi- predicacionales y mínimamente predicacionales. En cambio, la discusión sobre la construcción con genitivo compromete la perspectiva de descripción, ya que la función del genitivo como instrumento sintáctico no admite paralelo ni semejanza. Entrarían en esta categoría las estructuras que expresan cualidad, las que expresan pertenencia a una clase y las que predican posesión, pero tal distinción depende fundamentalmente del referente que tenga la palabra en genitivo, interpretable en función de las distinciones semánticas reconocibles por los competentes en una lengua. En este análisis se destaca la formalización a manera de locuciones de grupos de palabras que se asocian por costumbre. La contigüidad semántica facio-fio-sum explicaría que el verbo esse y el verbo facere compartieran la posibilidad de construirse con genitivo.

En la recopilación final se remite a la macrofunción Adscriptivo para la consideración semántica de estas relaciones de cualidad, inclusión, pertenencia e identificación. Una mirada a los modos de vida de la comunidad que empleaba el latín sugieren a la autora la secuencia de los niveles en que se entiende la posesión (pp.75-76). 
Esta estructura en todo caso se clasifica en el nivel predicacional más bajo. La selección de un nombre en dativo justifica, según el parecer de la autora, la comparación entre el uso de sum+dativo, el datiuus iudicantis y lo que llama 'dativo regido' (cap. III. 4). Los adjetivos " cuyo contenido semántico se encuentra fundamentalmente en torno a ideas de afección (benevolencia, amistad, agrado, etc.) cercanía, igualdad, utilidad, disposicióninclinación o sus análogas y contrarias" (p. 83) parecen merecer una atención particular de la autora. A propósito del uso del dativo con sum, se procede a una clasificación semántica (cualquier nombre animado o inanimado puede construirse con un dativo y sum) y cuantitativa de los términos que participan en las dos estructuras. No obstante, se corrobora la utilidad de la macrofunción Indirecto propuesta por Lehmann con las funciones particulares de Receptor, Beneficiario o Experimentante que se asocian al rasgo humano de un nombre en dativo en situaciones de acción o proceso.

La atención a la sintaxis del llamado "dativus iudicantis" que selecciona sujetos abstractos completa este panorama de una parte de los usos con dativo. Estas estructuras se adscriben al nivel mínimamente predicacional. Pero la construcción de doble dativo se trata en correspondencia con la de dativo final. La estructura de dativo posesivo se diferencia del esse copulativo propio de esta manera de expresar la finalidad. A ello contribuye la tendencia a la formalización de locuciones. Cuando el dativo posesivo se considera, se distinguen posesiones inalienable, permanente, física, temporal (en el ejemplo, un sueldo) inanimada inalienable y posesión abstracta. Del examen de la frecuencia de todas ellas, se extrae la observación de una tendencia a que la inalienable y la abstracta especialicen esta forma sintáctica. Plenamente predicativo resulta a juicio de la autora la estructura que se identifica con la noción 'existir para alguien' respecto de la de doble dativo, que es mínimamente predicacional.

La exposición concluye con las estructuras que integran un elemento locativo. De esta manera se cierra el abanico por el extremo más tendente a la predicación. Se consideran dentro del uso predicativo del verbo esse en contraste con las construcciones existenciales. De todo ello resulta una descripción del modo en que las nociones expuestas tienen su desarrollo en latín bastante distinto de anteriores análisis estructurales, que pretendían un acceso más abstracto y menos semántico de las funciones sintácticas. La selección de un corpus extenso pero limitado en la obra de Livio facilita la evidencia de los resultados. Una laboriosa confección de cuadros con los datos ordenados conforme a las hipótesis propuestas eleva el valor de este estudio. El indicio que la estadística proporciona nos muestra las tendencias más generales a la formalización de las estructuras sintácticas. La elección de alguno de los libros y no de todos podría haber distorsionado la percepción dada la diversidad con que se distribuye el contenido, las descripciones, los relatos, los discursos. La aplicación del mismo método se ha observado en la exposición de los capítulos, para que esta apariencia ordenada facilite la comparación de los resultados. Con todo, el balance de resultados se recoge de otra manera en la recapitulación final, en la que se tienen en cuenta las comparaciones anteriores bajo un aspecto sintético. 